\title{
MICROPROPAGATION OF CLERODENDRUM PHLOMIDIS L.F.
}

\author{
Mafatlal M. KHER ${ }^{1 *}$, Deepak SONER ${ }^{1}$, Neha SRIVASTAVA $^{1}$, Murugan NATARAJ $^{1 * *}$, \\ Jaime A. TEIXEIRA da SILVA ${ }^{2 * * *}$ \\ ${ }^{1}$ B.R. Doshi School of Biosciences, Sardar Patel University, Sardar Patel Maidan, Vadtal Road, \\ Satellite Campus, Post Box No. 39, Vallabh Vidyanagar-388120, India \\ ${ }^{2}$ P.O. Box 7, Miki-cho post office 3011-2, Ikenobe, Kagawa-ken 761-0799, Japan
}

Received: March 2016; Accepted: May 2016

\begin{abstract}
Clerodendrum phlomidis L. f. is an important medicinal plant of the Lamiaceae family, particularly its roots, which are used for various therapeutic purposes in a pulverized form. The objective of this study was to develop a standard protocol for axillary shoot proliferation and rooting of C. phlomidis for its propagation and conservation. Nodal explants were inoculated on Murashige and Skoog (MS) medium that was supplemented with one of six cytokinins: 6-benzyladenine, kinetin, thidiazuron, $N^{6}$-(2-isopentenyl) adenine (2iP), trans-zeatin (Zea) and meta-topolin. Callus induction, which was prolific at all concentrations, formed at the base of nodal explants and hindered shoot multiplication and elongation. To avoid or reduce callus formation with the objective of increasing shoot formation, the same six cytokinins were combined with $4 \mu \mathrm{M}$ 2,3,5-tri-iodobenzoic acid (TIBA) alone or in combination with $270 \mu \mathrm{M}$ adenine sulphate (AdS). Nodal explants that were cultured on the medium supplemented with $9.12 \mu \mathrm{M}$ Zea, $4 \mu \mathrm{M}$ TIBA and $270 \mu \mathrm{M}$ AdS produced significantly more and longer shoots than on medium without TIBA and AdS. Half-strength MS medium supplemented with $8.05 \mu \mathrm{M} \alpha$-naphthaleneacetic acid was the best medium for root formation. Most (75\%) in vitro rooted plantlets were successfully acclimatized under natural conditions.
\end{abstract}

Key words: auxin inhibitor; axillary shoot multiplication; callus; nodal explants; 2,3,5-tri-iodobenzoic acid

\section{INTRODUCTION}

Clerodendrum phlomidis L. f. (syn. C. multiflorum (Burm. f.) Kuntze; C. phlomidis f. rubrum (Roxb. ex Voigt) Moldenke; C. phlomidis var. rubrum Roxb. ex Voigt; Volkameria multiflora Burm. f.) is a member of the Lamiaceae family (The Plant List 2016). This shrub is distributed in India, Sri Lanka and Southeast Asia (Raja \& Mishra 2010) and is commonly known in India as Clerodendrum or wind killer in English and Arni in Hindi. C. phlomidis is an important medicinal plant used extensively in Ayurveda, Unani, Siddha and folklore medicines for the treatment of various types of ailments (Raja \& Mishra 2010) and is well known for the anti-inflammatory, anti-rheumatic and antiasthma activities of its root bark; antimicrobial acivity of its leaves; as well as antidiabetic, antimalarial, antiviral, antihypertensive, hypolipidemic and antioxidant activities of various plant parts (Shrivastava \& Patel 2007). The hexane and ethyl acetate extracts of roots show anti-tubercular activity against $\mathrm{Myco}$ bacterium tuberculosis H37Rv (Yadav \& Gupta 2014) - attributed to a phenylethanoid glycoside while the methanolic extract of its leaves has antidiarrhoeal properties (Rani et al. 1999). The aqueous extract of the root bark displays anti-inflammatory activity (Parekar et al. 2012). Yadav and Gupta (2014) attributed this activity to three compounds in the methanolic extract of roots, including lupeol. The chloroform extract of leaves show ovicidal and oviposition activities against Earias vittella (Muthu et al. 2013) because of the presence of the flavonoid pectolinaringenin and larvicidal activity against early fourth-instar larvae of the filarial vector Culex quinquefasciatus and dengue vector Aedes aegypti 
(Muthu et al. 2012), which is due to the presence of pectolinaringenin. The medicinal and biological properties of $C$. phlomidis are thus broad and firmly established.

Owing to these properties, C. phlomidis is a highly traded medicinal plant from tropical forests with an estimated consumption or trade of about 300 metric tons/year and is sold under the trade name of Arnimul (leaf and root), with a price ranging from 0.32 to $0.5 \mathrm{US} \$ / \mathrm{kg}$ (Raja \& Mishra 2010). Owing to its therapeutic importance, the plant is indiscriminately collected without any regulation, with a risk to natural populations. Therefore, there is interest in developing a suitable in vitro method for the mass propagation of $C$. phlomidis to reduce pressure on natural populations. Micropropagation by axillary shoot multiplication offers a simple but reliable, rapid and reproducible method for clonal propagation and germplasm conservation of threatened medicinally important plants. To date, several in vitro culture protocols have been developed for other members of the Clerodendrum genus (Nataraj et al. 2016), but only three reports on the micropropagation of $C$. phlomidis exist (Devika \& Kovilpillai 2012; Raaman et al. 2011; Soner et al. 2015). Devika and Kovilpillai (2012) and Raaman et al. (2011) used nodes and leaves as initial explants, while Soner et al. (2015) used leaves, internode and petiole explants to induce somatic embryogenesis of C. phlomidis. Raaman et al. (2011) induced shoots through an intermediate callus phase in the presence of 6-benzyladenine (BA) and $\alpha$-naphthaleneacetic acid (NAA) in Murashige and Skoog (1962) (MS) basal medium. Devika and Kovilpillai (2012) and Raaman et al. (2011) reported shoots from callus, but such callus can lead to somaclonal variation (Bairu et al. 2011). Although this is generally an undesirable outcome for clonal propagation, it can be beneficial in medicinal plants by obtaining plants with altered levels of secondary metabolites. Information about explant age, surface sterilization and culture conditions are not described by Devika and Kovilpillai (2012), making their protocol difficult to repeat, while somatic embryogenesis require further improvement (Soner et al. 2015). The present study describes a method for the in vitro propagation and multiplication of $C$. phlomidis through axillary bud proliferation from nodal explants and the successful acclimatization of regenerated plants in soil.

\section{MATERIALS AND METHODS}

\section{Plant material and surface sterilization}

Nodal cuttings of $C$. phlomidis were collected from the same 10-year-old mother plant growing in the Anand Agricultural University Medicinal Plant Garden, Anand, Gujarat. They were washed in running tap water for $10 \mathrm{~min}$. Explants (nodal cuttings with four nodes) were surface sterilized in sterile distilled water (SDW) containing a few drops of $10 \%(\mathrm{v} / \mathrm{v})$ Tween-20 followed by a $0.1 \%(\mathrm{w} / \mathrm{v})$ $\mathrm{HgCl}_{2}$ solution for $3 \mathrm{~min}$ followed by five rinses in SDW. Sterilized nodal explants were used for in vitro culture studies as described next.

\section{Composition of culture media and culture condi- tions}

The culture medium consisted of MS salts, vitamins and $3 \%(\mathrm{w} / \mathrm{v})$ sucrose. The $\mathrm{pH}$ of all media was adjusted to 5.8 with $0.1 \mathrm{~N} \mathrm{NaOH}$ or $\mathrm{HCl}$ before adding $0.8 \%$ (w/v) agar-agar (bacteriological grade; Merck, Ahmedabad, India) and autoclaved at $121{ }^{\circ} \mathrm{C}$ for $15 \mathrm{~min}$. Cultures were maintained at 25 $\pm 2{ }^{\circ} \mathrm{C}$ under a 16 -h photoperiod at a photosynthetic photon flux density of $35 \mu \mathrm{mol} \cdot \mathrm{m}^{-2} \cdot \mathrm{s}^{-1}$ provided by cool white fluorescent tubes (36W TL-D Super 80; Philips, Anand, India). All in vitro culture conditions were based on in-house optimization trials. Borosilicate glassware (Borosil, Bharuch, India) was used for all cultures within this study.

\section{Induction of axillary shoots on media containing different cytokinins}

Surface sterilized nodes, each with two vegetative buds, were inoculated in round glass bottles (400 ml capacity) containing Murashige and Skoog (1962) - MS medium supplemented with 2.22, 4.44, 6.66, 8.88 and $11.1 \mu \mathrm{M}$ of 6-benzyladenine (BA); $2.33,4.65,6.98,9.30$ and $11.63 \mu \mathrm{M}$ of 6-furfurylaminopurine (kinetin, $\mathrm{Kn}$ ); 2.46, 4.92, 7.38, 9.84 and $12.3 \mu \mathrm{M}$ of $N^{6}$-(2-isopentenyl) adenine (2iP); 2.07, $4.14,6.21,8.28$ and $10.35 \mu \mathrm{M}$ of 6-(3-hydroxybenzylamino) purine meta-topolin, $m \mathrm{~T}) ; 2.28,4.56$, $6.84,9.12$ and $11.4 \mu \mathrm{M}$ of 6-(4-hydroxy-3methylut-2-enylamino)purine (trans-zeatin, Zea), all purchased from Himedia (Mumbai, India) and 
$2.27,4.54,6.81,9.08,11.35 \mu \mathrm{M}$ of 1-phenyl-3(1,2,3-thiadiazol-5-yl)urea) (thidiazuron, TDZ), purchased from Sigma (Bangalore, India) for axillary shoot multiplication. After two weeks of culture, prolific callus formed at the cut ends of nodal explants, which inhibited effective shoot formation and multiplication (Fig. 1A).

\section{Influence of TIBA and AdS on axillary shoot multiplication}

To prevent an excessive amount of callus formation, nodal explants were cultured in round glass bottles (400 ml capacity) containing MS medium supplemented with $4 \mu \mathrm{M}$ of 2,3,5-tri-iodobenzoic acid (TIBA) (Himedia), a polar auxin inhibitor, and $8.88 \mu \mathrm{M}$ of BA, $9.3 \mu \mathrm{M}$ of $\mathrm{Kn}, 9.84 \mu \mathrm{M}$ of $2 \mathrm{iP}$, $8.28 \mu \mathrm{M}$ of $m \mathrm{~T}, 9.12 \mu \mathrm{M}$ of Zea or $9.08 \mu \mathrm{M}$ of TDZ alone or in combination with $270 \mu \mathrm{M}$ of adenine sulphate (AdS) (Himedia), which was determined to be the optimal concentration in a pre-trial.

\section{Rooting and acclimatization}

Shoots that developed in vitro $4-5 \mathrm{~cm}$ in length were excised and transferred to test tubes containing half-strength MS medium supplemented with 2.69, 5.37, 8.05 and $10.73 \mu \mathrm{M}$ of $\alpha$-naphthaleneacetic acid (NAA) or $2.46,4.9,7.34$ and $9.78 \mu \mathrm{M}$ of indole-3-butyric acid (IBA) (Himedia) for root induction. Plantlets with well-developed roots were removed and gently washed in running tap water to remove adhering medium. Subsequently, they were transferred to plastic cups containing sterile sand, cocopeat and soil mixture in a $1: 1: 1$ ratio. The transplanted plants were covered with clear transparent plastic bags to maintain humidity, placed in plant tissue culture laboratory and watered with $15 \mathrm{ml}$ of $1 / 4 \mathrm{MS}$ (quarter-strength of macro- and micronutrients) at 4-day intervals. After 15 days, the plastic bags were opened and the uncovered plants were maintained at $25^{\circ} \mathrm{C}$ under a 16 -h photoperiod and $35 \mu \mathrm{mol} \cdot \mathrm{m}^{-2} \cdot \mathrm{s}^{-1}$ in the laboratory. After 30 days, plantlets were transplanted to the field under natural conditions.

\section{Statistical analysis}

All experiments were conducted at least three times with 12 replicates (i.e., explants) per treatment and evaluated after 45 days. Data from all experients were subjected to one-way analysis of variance (ANOVA), and mean comparison was analyzed by
Duncan's multiple range test (DMRT) at $p=0.05$ using Statistical Package for Social Science (SPSS) ver. 19 for Windows (SPSS Inc., Chicago, IL, USA). Results were expressed as means \pm standard deviation (SD).

\section{RESULTS AND DISCUSSION}

\section{Axillary shoot growth and multiplication}

Nodal segments are preferred explants for micropropagation because of the presence of pre-existing meristems, which can develop easily into shoots while maintaining clonal fidelity. In this study, nodal explants of $C$. phlomidis were inoculated on MS basal medium supplemented with different concentrations of a single cytokinin (BA, Kn, TDZ, 2iP, Zea and $m \mathrm{~T}$ ), while cultures without plant growth regulators (PGRs) served as the control. Sprouting of axillary shoots was recorded only on 11 media, always in the highest concentration of the cytokinins. The participation of nodal explants with sprouted shoots was low - from $8.3(\mathrm{mT})$ to $33.3 \%$ (Zea). When shoots formed, bud break was observed 7-10 days after plating for any cytokinin tested. Nodal explants that were cultured on the medium supplemented with 9.12 and $11.4 \mu \mathrm{M}$ Zea or 8.88 and $11.1 \mu \mathrm{M}$ BA resulted in the formation of the highest number of shoots/node (2.3 and 1.9, and 1.8 and 1.7 respectively) after about 45 days (Table 1). All explants, also those cultured on the medium without cytokinin, formed excessive callus at the base of nodal explants (Fig. 1A). Callus also formed at the base of $C$. colebrookianum Walp nodal explants when cultured on Woody Plant Medium (WPM; Lloyd and McCown, 1980) supplemented with $4.44 \mu \mathrm{M}$ BA (Mao et al. 1995). The formation of callus at cut ends of nodal explants may be due to the presence of a high concentration of endogenous auxins, which leads to a wounding response (Bernabé-Antonio et al. 2012; Ikeuchi et al. 2013; Motte et al. 2014). The formation of callus during axillary shoot multiplication significantly hindered shoot number and length (Table 1). TIBA, a well-known auxin inhibitor, blocks polar auxin transport (Gurel et al. 2008). To reduce or avoid excessive callus formation, $4 \mu \mathrm{M}$ TIBA was added in combination with six cytokinins, alone or with $270 \mu \mathrm{M}$ AdS (Table 2). 
This approach successfully produced the most (5.4 $\pm 1.7 /$ node $)$ and longest $(3.4 \pm 0.4 \mathrm{~cm})$ shoots without callus in the presence of $9.12 \mu \mathrm{M}$ Zea, $4 \mu \mathrm{M}$ TIBA and $270 \mu \mathrm{M}$ AdS (Table 2; Fig. 1D), although shoot number was not significantly different to the combinations $2 \mathrm{iP}+\mathrm{TIBA}+\mathrm{AdS}, m \mathrm{~T}+\mathrm{TIBA}+$ AdS and TDZ + TIBA + AdS, and shoot length was not significantly different to the $m \mathrm{~T}+\mathrm{AdS}$ and Zea combinations.

Table 1. Effects of cytokinins and their concentration on Clerodendrum phlomidis nodal explants cultured on MS medium

\begin{tabular}{|c|c|c|c|c|c|}
\hline Cytokinin & $\begin{array}{l}\text { Concentration } \\
\qquad(\mu \mathrm{M})\end{array}$ & $\begin{array}{l}\text { Growth of } \\
\text { shoots from } \\
\text { nodal buds } \\
\text { (\% response) }\end{array}$ & $\begin{array}{l}\text { Number of } \\
\text { shoots/node }\end{array}$ & $\begin{array}{l}\text { Shoot length } \\
\quad(\mathrm{cm})\end{array}$ & Callus $^{1}$ \\
\hline \multirow[t]{3}{*}{0 (Control) } & 0.00 & -- & -- & -- & $* * * *$ \\
\hline & 2.46 & -- & -- & -- & $* * * *$ \\
\hline & 4.92 & -- & -- & -- & $* * * *$ \\
\hline \multirow[t]{5}{*}{$2 \mathrm{iP}$} & 7.38 & -- & -- & -- & $* * * *$ \\
\hline & 9.84 & -- & -- & -- & $* * * *$ \\
\hline & 12.3 & 16.7 & $1.5 \pm 0.7 \mathrm{bcd}$ & $0.7 \pm 0.2 \mathrm{~d}$ & $* * * *$ \\
\hline & 2.22 & -- & -- & -- & $* * * *$ \\
\hline & 4.44 & -- & -- & -- & $* * * *$ \\
\hline \multirow[t]{5}{*}{ BA } & 6.66 & -- & -- & -- & $* * * *$ \\
\hline & 8.88 & 29.2 & $1.8 \pm 0.6 \mathrm{abc}$ & $1.3 \pm 0.4 \mathrm{ab}$ & $* * *$ \\
\hline & 11.1 & 25.0 & $1.7 \pm 0.8 \mathrm{abcd}$ & $1.3 \pm 0.35 \mathrm{ab}$ & $* * *$ \\
\hline & 2.33 & -- & -- & -- & $* * * *$ \\
\hline & 4.65 & -- & -- & -- & $* * * *$ \\
\hline \multirow[t]{5}{*}{$\mathrm{Kn}$} & 6.98 & -- & -- & -- & $* * * *$ \\
\hline & 9.30 & -- & -- & -- & $* * * *$ \\
\hline & 11.63 & 16.7 & $1.5 \pm 0.5 \mathrm{bcd}$ & $1.3 \pm 0.3 \mathrm{a}$ & $* * *$ \\
\hline & 2.07 & -- & -- & -- & $* * * *$ \\
\hline & 4.14 & -- & -- & -- & $* * * *$ \\
\hline \multirow[t]{5}{*}{$m \mathrm{~T}$} & 6.21 & -- & -- & -- & $* * * *$ \\
\hline & 8.28 & 12.5 & $1.3 \pm 0.5 \mathrm{~cd}$ & $0.9 \pm 0.3 \mathrm{~cd}$ & $* * * *$ \\
\hline & 10.35 & 8.3 & $1.1 \pm 0.4 \mathrm{~d}$ & $0.9 \pm 0.3 \mathrm{~cd}$ & $* * * *$ \\
\hline & 2.27 & -- & -- & -- & $* * * *$ \\
\hline & 4.54 & -- & -- & -- & $* * * *$ \\
\hline \multirow[t]{5}{*}{ TDZ } & 6.81 & -- & -- & -- & $* * * *$ \\
\hline & 9.08 & 20.8 & $1.6 \pm 0.7 \mathrm{bcd}$ & $1.1 \pm 0.2 \mathrm{abc}$ & $* * *$ \\
\hline & 11.35 & 16.7 & $1.3 \pm 0.5 \mathrm{bcd}$ & $1.0 \pm 039 b c$ & $* * * *$ \\
\hline & 2.28 & -- & -- & -- & $* * * *$ \\
\hline & 4.56 & -- & -- & -- & $* * * *$ \\
\hline \multirow[t]{3}{*}{ Zea } & 6.84 & 20.8 & $1.6 \pm 0.7 \mathrm{bcd}$ & $1.2 \pm 0.2 \mathrm{ab}$ & $* * *$ \\
\hline & 9.12 & 29.2 & $2.3 \pm 0.8 \mathrm{a}$ & $1.1 \pm 0.3 \mathrm{abc}$ & $* * *$ \\
\hline & 11.4 & 33.3 & $1.9 \pm 0.7 \mathrm{ab}$ & $1.2 \pm 0.4 \mathrm{ab}$ & $* * *$ \\
\hline
\end{tabular}

Values represent means \pm SD. Means followed by the same letter within each column are not significantly different according to Duncan's multiple range test at $\mathrm{p}=0.05(\mathrm{n}=36)$. Data were recorded after 45 days. ${ }^{1}$ Percentage of explants that formed callus at the base of nodal explants:, $* * *=51-75 \%, * * * *=76-100 \%$. 
Table 2. Effects of various combinations of cytokinin with 2,3,5-tri-iodobenzoic acid (TIBA) and adenine sulphate (AdS) on Clerodendrum phlomidis nodal explants cultured on MS medium

\begin{tabular}{cclcc}
\hline Cytokinin + TIBA $(4 \mu \mathrm{M})$ & $\begin{array}{c}\text { AdS } \\
(\mu \mathrm{M})\end{array}$ & $\begin{array}{c}\text { Number of } \\
\text { shoots/node }\end{array}$ & $\begin{array}{c}\text { Shoot length } \\
(\mathrm{cm})\end{array}$ & Callus $^{2}$ \\
\hline 2iP $9.84 \mu \mathrm{M}$ & -- & $2.7 \pm 1.4 \mathrm{c}$ & $2.9 \pm 0.1 \mathrm{bc}$ & -- \\
2iP $9.84 \mu \mathrm{M}$ & 271 & $4.2 \pm 1.5 \mathrm{ab}$ & $2.8 \pm 0.3 \mathrm{bcd}$ & -- \\
BA $8.88 \mu \mathrm{M}$ & -- & $1.8 \pm 0.8 \mathrm{c}$ & $2.87 \pm 0.3 \mathrm{~cd}$ & $*$ \\
BA $8.88 \mu \mathrm{M}$ & 271 & $2.0 \pm 0.8 \mathrm{c}$ & $3.0 \pm 0.3 \mathrm{bc}$ & $*$ \\
Kn $9.30 \mu \mathrm{M}$ & -- & $2.2 \pm 0.8 \mathrm{c}$ & $2.5 \pm 0.3 \mathrm{~d}$ & $* *$ \\
Kn $9.30 \mu \mathrm{M}$ & 271 & $3.2 \pm 1.3 \mathrm{bc}$ & $3.0 \pm 0.3 \mathrm{bc}$ & $* *$ \\
$m \mathrm{~T} 8.28 \mu \mathrm{M}$ & -- & $2.50 \pm 0.9 \mathrm{c}$ & $3.0 \pm 0.5 \mathrm{bc}$ & -- \\
$m \mathrm{~T} 8.28 \mu \mathrm{M}$ & 271 & $4.9 \pm 1.5 \mathrm{a}$ & $3.2 \pm 0.3 \mathrm{ab}$ & $*$ \\
TDZ $9.08 \mu \mathrm{M}$ & -- & $1.8 \pm 0.8 \mathrm{c}$ & $2.9 \pm 0.3 \mathrm{bc}$ & $* *$ \\
TDZ $9.08 \mu \mathrm{M}$ & 271 & $4.3 \pm 1.3 \mathrm{ab}$ & $2.9 \pm 0.4 \mathrm{bc}$ & -- \\
Zea $9.12 \mu \mathrm{M}$ & -- & $2.8 \pm 1.2 \mathrm{c}$ & $3.2 \pm 0.5 \mathrm{ab}$ & -- \\
Zea $9.12 \mu \mathrm{M}$ & 271 & $5.4 \pm 1.7 \mathrm{a}$ & $3.4 \pm 0.4 \mathrm{a}$ & - \\
\hline
\end{tabular}

Values represent means \pm SD. Means followed by the same letter within each column are not significantly different according to Duncan's multiple range test at $\mathrm{p}=0.05(\mathrm{n}=36)$. Data were recorded after 45 days. All experiments were performed on MS (Murashige \& Skoog 1962) medium.

${ }^{1}$ Percentage of explants that formed callus at the base of each nodal explant: * $=0-25 \%, * *=26-50 \%$
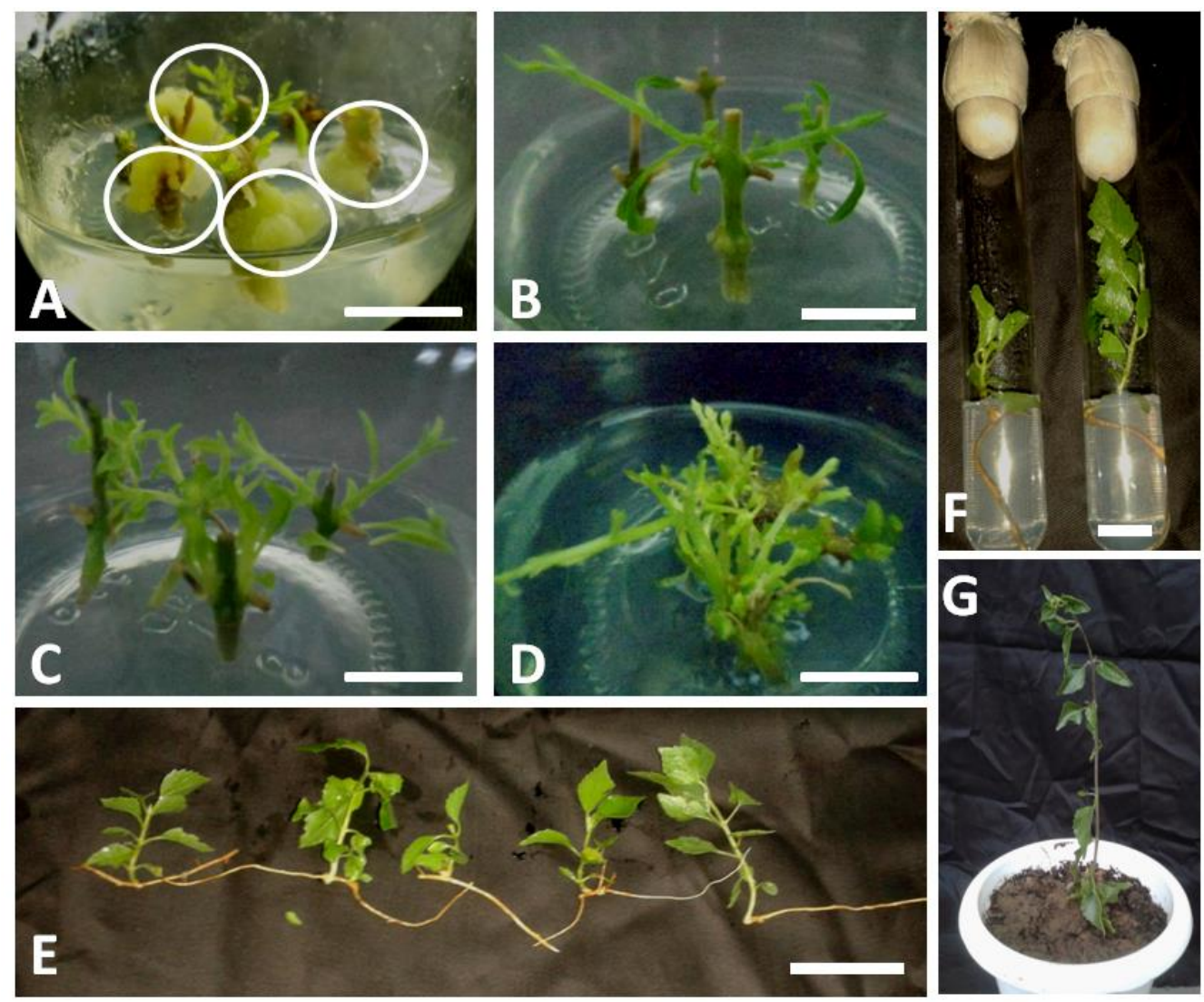

Fig. 1. Micropropagation of Clerodendrum phlomidis on MS medium. (A) Callus formation from nodal cut ends on the medium containing $9.12 \mu \mathrm{M}$ Zea. (B) Axillary shoot multiplication on the medium containing $8.88 \mu \mathrm{M}$ BA and $4 \mu \mathrm{M}$ TIBA. (C) Axillary shoot multiplication on the medium containing $9.12 \mu \mathrm{M}$ Zea and $4 \mu \mathrm{M}$ TIBA. (D) Axillary shoot multiplication on the medium containing $9.12 \mu \mathrm{M}$ Zea, $4 \mu \mathrm{M}$ TIBA and $271 \mu \mathrm{M}$ AdS. (E) In vitro rooted shoots on $1 / 2$ MS medium containing $7.34 \mu \mathrm{M}$ IBA. (F) In vitro rooted shoots on $1 / 2$ MS medium containing $8.05 \mu$ M NAA. (G) 2 months after transplanting from in vitro conditions. Bars: $\mathrm{A}=5.0 \mathrm{~cm} ; \mathrm{B}, \mathrm{C}, \mathrm{D}$ and $\mathrm{E}=2.50 \mathrm{~cm} ; \mathrm{F}=1.0 \mathrm{~cm}$ 
In contrast, medium supplemented with TIBA in combination with $2 \mathrm{iP}$ and Zea resulted in fewer shoots without callus (Fig. 1B, 1C), while callus formed simultaneously with shoots on MS medium supplemented with BA, Kn and TDZ in conjunction with $4 \mu \mathrm{M}$ TIBA and $270 \mu \mathrm{M}$ AdS (Table 2). Shukla et al. (2014) reported that callus formation inhibits shoot formation in two-day old cotyledon explants of Cucumis sativus L. cultivars (Pant Kheera 1 and Pusa Uday) because of the presence of endogenous indole3 -acetic acid (IAA). They found that the addition of TIBA significantly reduced the endogenous level of IAA, which also improved shoot formation. TIBA $(5 \mu \mathrm{M})$ was successfully applied in combination with Zea $(1.14 \mu \mathrm{M})$ to overcome callusing in Indian tetraploid potato (Solanum tuberosum L.) (Pal et al. 2011). Devika and Kovilpillai (2012) induced shoots from $87 \%$ nodes of $C$. phlomidis in the presence of $13.32 \mu \mathrm{M}$ BA and $2.69 \mu \mathrm{M}$ NAA.

\section{Rooting and acclimatization}

All media, whether supplemented with an auxin, or not, resulted in the formation of initial roots within 10 days and took 30-45 days for a welldeveloped root system to form (Table 3; Fig. 1E, $1 F)$. The most effective rooting medium was halfstrength MS medium supplemented with $8.05 \mu \mathrm{M}$ NAA, forming 3.8 roots/shoot that were $1.8 \mathrm{~cm}$ long. Mao et al. (1995) obtained roots on PGR-free WPM medium in C. colebrookianum Walp., Goyal et al. (2010) obtained $1.3 \pm 0.15$ shoots on halfstrength MS medium without PGRs for $C$. insicum L., while Kothari et al. (2006) successfully rooted $C$. inerme (L.) Gaertn. on PGR-free MS medium. Medium containing $8.05 \mu \mathrm{M}$ NAA formed most roots, although this result was not significantly different from results obtained on the media containing other auxins (Table 3). Devika and Kovilpillai (2012) obtained $7.3 \pm 0.94$ roots from in vitro raised shoots of $C$. phlomidis on MS medium supplemented with $9.78 \mu \mathrm{M}$ IBA. NAA-induced in vitro rooting was also reported in C. colebrookianum (Mao et al. 1995) and C. insicum (Goyal et al. 2010). In C. aculeatum, in vitro-raised shoots rooted in MS medium with $0.50 \mathrm{mg} \cdot \mathrm{dm}^{-3}(2.69 \mu \mathrm{M}) \mathrm{NAA}$ and $0.50 \mathrm{mg} \cdot \mathrm{dm}^{-3}(2.46 \mu \mathrm{M})$ IBA (Srivastava et al. 2004). In C. serratum, $1 \mathrm{mg} \cdot \mathrm{dm}^{-3}(5.3 \mu \mathrm{M})$ indole3-propionic acid was a more effective auxin than IAA, IBA, $\alpha$-naphthoxyacetic acid, NAA and IBA (Sharma et al. 2009). In our experiment, $75 \%$ plants successfully survived under natural conditions (Fig. $1 \mathrm{G})$. This paper describes a robust and reproducible protocol for the micropropagation of $C$. phlomidis using nodal explants and can be applied for conservation of this medicinally important plant.

Table 3. Effects of various concentrations of two auxins on in vitro rooting of 4-5-cm C. phlomidis in vitro raised shoots derived from MS medium supplemented with $9.12 \mu \mathrm{M}$ Zea, $271 \mu \mathrm{M}$ AdS and $4 \mu \mathrm{M}$ TIBA

\begin{tabular}{cccc}
\hline $\mathrm{IBA}^{1}(\mu \mathrm{M})$ & $\mathrm{NAA}^{1}(\mu \mathrm{M})$ & Number of roots/shoot & Root length $(\mathrm{cm})$ \\
\hline 0 & -- & $1.3 \pm 0.6 \mathrm{~b}$ & $0.5 \pm 0.3 \mathrm{~g}$ \\
2.46 & -- & $2.4 \pm 1.1 \mathrm{ab}$ & $0.8 \pm 0.4 \mathrm{fg}$ \\
4.9 & -- & $2.4 \pm 1.1 \mathrm{ab}$ & $0.8 \pm 0.4 \mathrm{def}$ \\
7.34 & -- & $3.0 \pm 1.6 \mathrm{ab}$ & $1.1 \pm 0.3 \mathrm{cde}$ \\
9.78 & -- & $2.3 \pm 1.0 \mathrm{ab}$ & $1.3 \pm 0.4 \mathrm{cde}$ \\
-- & 2.69 & $2.8 \pm 2.0 \mathrm{ab}$ & $1.6 \pm 0.5 \mathrm{abc}$ \\
-- & 5.37 & $2.9 \pm 1.0 \mathrm{ab}$ & $1.4 \pm 0.6 \mathrm{bcd}$ \\
-- & 8.05 & $3.8 \pm 1.1 \mathrm{a}$ & $1.8 \pm 0.8 \mathrm{ab}$ \\
-- & 10.73 & $2.5 \pm 1.67 \mathrm{ab}$ & $2.0 \pm 1.0 \mathrm{a}$ \\
\hline
\end{tabular}

Values represent means \pm SD. Means followed by the same letter within each column are not significantly different according to Duncan's multiple range test $\mathrm{p}=0.05(\mathrm{n}=36)$. Data were recorded after 45 days.

${ }^{1}$ 0: control treatment. All experiments were performed on half-strength MS (Murashige \& Skoog 1962) medium. 


\section{REFERENCES}

Bairu M.W., Aremu A.O., van Staden J. 2011. Somaclonal variation in plants: causes and detection methods. Plant Growth Regulation 63(2): 147173. DOI: 10.1007/s10725-010-9554-x.

Bernabé-Antonio A., Santacruz-Ruvalcaba F., Cruz-Sosa F. 2012. Effect of plant growth regulators on plant regeneration of Dioscorea remotiflora (Kunth) through nodal explants. Plant Growth Regulation 68(2): 293-301. DOI: 10.1007/s10725-012-9717-z.

Devika R., Kovilpillai J. 2012. Phytochemical and in vitro micropropagation studies of Clerodendrum phlomidis L. Journal of Pharmacy Research 5(8): 4396-4398.

Goyal S., Shahzad A., Anis M., Khan S. 2010. Multiple shoot regeneration in Clerodendrum incisum L. an ornamental woody shrub. Pakistan Journal of Botany 42(2): 873-878.

Gurel E., Gurel S., Lemaux P.G. 2008. Biotechnology applications for sugar beet. Critical Reviews in Plant Sciences 27(2): 108-140. DOI: 10.1080/07352680802202000.

Ikeuchi M., Sugimoto K., Iwase A. 2013. Plant callus: mechanisms of induction and repression. Plant Cell 25(9): 3159-3173. DOI: 10.1105/tpc.113.116053.

Kothari A., Padh H., Shrivastava N. 2006. Ex situ conservation method for Clerodendrum inerme: a medicinal plant of India. African Journal of Biotechnology 5(5): 415-418.

Lloyd G., McCown B. 1980. Commercially-feasible micropropagation of mountain laurel, Kalmia latifolia, by use of shoot-tip culture. International Plant Propagators' Society 30: 421-427.

Mao A.A., Wetten A., Fay M., Caligari P.D. 1995. In vitro propagation of Clerodendrum colebrookianum Walp., a potential natural anti-hypertension medicinal plant. Plant Cell Reports 14(8): 493-496. DOI: $10.1007 / \mathrm{BF} 00232781$.

Motte H., Vereecke D., Geelen D., Werbrouck S. 2014. The molecular path to in vitro shoot regeneration. Biotechnology Advances 32(1): 107-121. DOI: 10.1016/j.biotechadv.2013.12.002.

Murashige T., Skoog F. 1962. A revised medium for rapid growth and bio assays with tobacco tissue cultures. Physiologia Plantarum 15: 473-497. DOI: 10.1111/j.1399-3054.1962.tb08052.x.

Muthu C., Baskar K., Ignacimuthu S., Al-Khaliel A.S. 2013. Ovicidal and oviposition deterrent activities of the flavonoid pectolinaringenin from Clerodendrum phlomidis against Earias vittella.
Phytoparasitica 41: 365-372. DOI: 10.1007/s12600-013-0296-y.

Muthu C., Reegan A.D., Kingsley S., Ignacimuthu S. 2012. Larvicidal activity of pectolinaringenin from Clerodendrum phlomidis L. against Culex quinquefasciatus Say and Aedes aegypti L. (Diptera: $\mathrm{Cu}$ licidae). Parasitology Research 111(3): 1059-65. DOI: 10.1007/s00436-012-2932-8.

Nataraj M., Kher M.M., Teixeira da Silva J.A. 2016. Micropropagation of Clerodendrum L. species: a review. Rendiconti Lincei. Scienze Fisiche e Naturali 27(2):169-179. DOI: 10.1007/s12210-015-0484-4.

Pal A.K., Acharya K., Ahuja P.S. 2011. Endogenous auxin level is a critical determinant for in vitro adventitious shoot regeneration in potato (Solanum tuberosum L.). Journal of Plant Biochemistry and Biotechnology 21: 205-212. DOI: 10.1007/s13562011-0092-z.

Parekar R.R., Dash K.K., Marathe P.A., Apte A.A., Rege N.N. 2012. Evaluation of anti-inflammatory activity of root bark of Clerodendrum phlomidis in experimental models of inflammation. International Journal of Applied Biology and Pharmaceutical Technology 3(3): 54-60.

Raaman N., Divakar S., Jeyam P., Hariprasath L., Baskar M., Mathiyazhagan K. 2011. Micropropagation, antimicrobial activity and phytochemical analysis of Clerodendron phlomidis Linn. Medicinal Plants 3(2): 119-127. DOI: 10.5958/j.0975-4261.3.2.019.

Raja M.M.M.K., Mishra S.H. 2010. Comprehensive review of Clerodendrum phlomidis: a traditionally used bitter. Journal of Chinese Integrative Medicine 8(6): 510-524.

Rani S., Ahamed N., Rajaram S., Saluja R., Thenmozhi S., Murugesan T. 1999. Anti-diarrhoeal evaluation of Clerodendrum phlomidis Linn. leaf extract in rats. Journal of Ethnopharmacology 68(1-3): 315319. DOI: 10.1016/S0378-8741(99)00103-8.

Sharma M., Rai S.K., Purshottam D.K., Jain M., Chakrabarty D., Awasthi A., Nair K.N., Sharma A.K. 2009. In vitro clonal propagation of Clerodendrum serratum (Linn.) Moon (barangi): a rare and threatened medicinal plant. Acta Physiologiae Plantarum 31: 379-383. DOI: 10.1007/s11738-008-0245-4.

Shrivastava N., Patel T. 2007. Clerodendrum and heathcare: an overview. Medicinal and Aromatic Plant Science and Biotechnology 1(1): 142-150.

Shukla P.S., Das A.K., Jha B., Agarwal P.K. 2014. Highfrequency in vitro shoot regeneration in Cucumis sativus by inhibition of endogenous auxin. In Vitro 
Cellular \& Developmental Biology - Plant 50: 729737. DOI: $10.1007 / \mathrm{s} 11627-014-9649-6$.

Soner D., Nataraj M., Kher M.M. 2015. Somatic embryogenesis in Clerodendrum phlomidis L. Academic Journal of Plant Sciences 7(1): 6-9. DOI: 10.5829/idosi.ajps.2015.7.1.9267.

Srivastava A., Gupta R.K., Verma H.N. 2004. Micropropagation of Clerodendrum aculeatum through adventitious shoot induction and production of consistent amount of virus resistance inducing protein. Indian Journal of Experimental Biology 42: 1200-1207.
The Plant List 2016. Clerodendrum phlomidis L.f. URL http://www.theplantlist.org/tpl/record/kew-42945 (accessed 20 April 2016).

Yadav A.K., Gupta M.M. 2014. Simultaneous quantification of the anti-inflammatory phytoconstituents

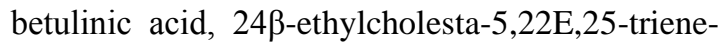
$3 \beta$-ol, and lupeol in Clerodendrum phlomidis. Journal of Planar Chromatography - Modern TLC 27(3): 174-180. DOI: 10.1556/JPC.27.2014.3.5. 